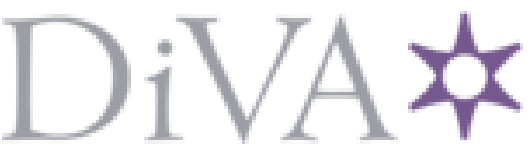

http://www.diva-portal.org

\title{
Postprint
}

This is the accepted version of a paper published in . This paper has been peer-reviewed but does not include the final publisher proof-corrections or journal pagination.

Citation for the original published paper (version of record):

Di Baldassarre, G., Wanders, N., AghaKouchak, A., Kuil, L., Rangecroft, S. et al. (2018)

Water shortages worsened by reservoir effects

Nature Sustainability, 1: 617-622

https://doi.org/10.1038/s41893-018-0159-o

Access to the published version may require subscription.

N.B. When citing this work, cite the original published paper.

Permanent link to this version:

http://urn.kb.se/resolve?urn=urn:nbn:se:uu:diva-366446 


\section{Water shortages worsened by reservoir effects}

Giuliano Di Baldassarre ${ }^{1,2}$, Niko Wanders ${ }^{3}$, Amir AghaKouchak ${ }^{4,5}$, Linda Kuil ${ }^{6}$, Sally Rangecroft ${ }^{7}$, Ted I.E. Veldkamp ${ }^{8}$, Margaret Garcia ${ }^{9}$, Pieter R. van Oel ${ }^{10}$, Korbinian Breinl ${ }^{1,2}$, and Anne F. Van Loon ${ }^{7}$

${ }^{1}$ Department of Earth Sciences, Uppsala University, Uppsala, Sweden

${ }^{2}$ Centre of Natural Hazards and Disaster Science, CNDS, Sweden

${ }^{3}$ Department of Physical Geography, Utrecht University, Utrecht, The Netherlands

${ }^{4}$ Department of Civil and Environmental Engineering, University of California, Irvine, USA

${ }^{5}$ Department of Earth System Science, University of California, Irvine, USA

${ }^{6}$ Centre for Water Resource Systems, Vienna University of Technology, Vienna, Austria

${ }^{7}$ School of Geography, Earth and Environmental Sciences, University of Birmingham, Birmingham, UK

${ }^{8}$ Water and Climate Risk Department, VU Amsterdam, Amsterdam, The Netherlands

${ }^{9}$ School of Sustainable Engineering and the Built Environment, Arizona State University, USA

${ }^{10}$ Environmental Sciences Group, Wageningen University, Wageningen, The Netherlands

The expansion of reservoirs to cope with droughts and water shortages is hotly debated in many places around the world. We argue that there are two counterintuitive dynamics that should be considered in this debate: supply-demand cycles and reservoir effects. Supply-demand cycles describe instances where increasing water supply enables higher water demand, which can quickly offset the initial benefits of reservoirs. Reservoir effects refer to cases where over-reliance on reservoirs increases vulnerability, and therefore increases the potential damage caused by droughts. Here we illustrate these counterintuitive dynamics with global and local examples, and discuss policy and research implications.

Throughout history, societies have been severely affected by drought. The collapse of various ancient civilizations, such as the Maya, has been attributed to prolonged periods of drought ${ }^{1}$. Individuals, communities, and societies have reacted and adapted to drought primarily by exploiting groundwater, building dams and expanding infrastructure for surface water storage and transfer, which aim to stabilize water availability. Consequently, the hydrological regime has become highly artificial in many regions of the world ${ }^{2,3}$, and low flow conditions are influenced by both climatic and anthropogenic factors ${ }^{4-6}$, including reservoir management ${ }^{7,8}$.

Drought occurrences can trigger temporary reductions of water availability, often leading to water shortages when water demand cannot be satisfied by the available water. Societal responses to water shortages can result in a series of cascading effects. The blue loop of Figure 1 shows one traditional response: the expansion of reservoir storage. More specifically, economic damage from water shortages triggers public pressure for action, which can then result in the expansion of reservoirs to increase water availability (blue arrows in Fig. 1). This response tends to decrease the frequency, severity, and duration of water shortage (Fig. 1, negative feedback between supply and shortage).

Dams and reservoirs can supply a reliable source of water ${ }^{9,10}$, and are key for a variety of human activities and needs ${ }^{11}$. Over the past 100 years, the number, and total storage capacity, of large dams and reservoirs has rapidly increased ${ }^{12-14}$. More than half of the world's reservoirs are designed and managed to supply water for domestic, industrial and agricultural purposes ${ }^{12}$. These reservoirs store water during periods of excess, to bridge periods of water deficit or increased demand. Other dams and reservoirs provide different services, such as flood control and hydropower generation ${ }^{12}$.

There are ongoing discussions in many areas around the world about potential new reservoirs to increase water availability. The impact of hydro-climatic and socio-economic trends is part of these debates ${ }^{15,16}$. In water management and planning ${ }^{16}$, hydro-climatic trends derived from climate projections are utilized to better understand future water availability in the coming decades ${ }^{17}$ (e.g. decreasing streamflow). Socio-economic trends from various scenarios (e.g. population growth) inform projections of future water demand ${ }^{16}$. The grey arrows in Figure 1 indicate the potential role of these two external drivers of change: hydro-climatic and socio-economic trends. 
Reservoirs have enabled economic growth and poverty alleviation in many regions around the world ${ }^{18}$. Notably, the benefits accrued depend not only on the construction of reservoirs, but also on the development of institutional or human capacities to manage such water infrastructure ${ }^{19}$, and effectively use the available water for agricultural, industrial or civil purposes.

When considering the benefits of additional reservoir capacity, it is important to consider perspectives from multiple stages of economic growth ${ }^{20}$. Most high-income countries have reaped the benefits of reservoir construction by developing the majority of their feasible storage capacity, while many lowand middle-income countries have further potential for reservoir development ${ }^{19}$. The United States, and other high-income countries, have transitioned from an era of reservoir expansion to an era of environmental protection and soft-path approaches ${ }^{21}$. Yet, in low- and middle income countries, many new reservoirs are still being planned or built, such as the Grand Ethiopian Renaissance Dam ${ }^{22,23}$.

Despite clear benefits, dams remain controversial. The operation and construction of reservoirs require significant capital investments that do not always pay off ${ }^{24}$. Aside from financial risks, dams are often socially and politically contested due to their potentially negative impacts on environment and society ${ }^{11,16,21,25}$. As a result, proposals for new reservoirs often encounter resistance from the local population, facing displacement or ecological degradation in their communities.

Moreover, we know that the benefits of reservoirs are not equally distributed between upstream and downstream regions. They may likewise be counteracted by increases in evaporation, sedimentation, and unfavourable temporal and spatial redistribution of water resources ${ }^{4,5}$. As a result, while reservoirs can alleviate hydrological drought in certain areas, they can enhance it in others ${ }^{26,27}$.

A prominent negative example is the drying of numerous lakes and wetlands around the world due to continuously increasing water depletion using irrigation systems, which are supplied by water from reservoirs. For example, Lake Urmia, in northwest Iran, was once the second largest saltwater lake on Earth. Over the past 40 years, its area has decreased by around $80 \%$, with most of the change occurring from $2009^{28}$. Since 2000, 20 dams started operation in the lake's basin ${ }^{29}$, diverting the lake's freshwater inflow for irrigation and farming purposes, leading to noticeable environmental degradation ${ }^{30}$.

Besides stressed lakes, another important negative impact is the so-called closure of river basins ${ }^{31,32}$ where no (or limited) usable water reaches the basin's outlet. Prominent examples are the Colorado, Indus, and Murray-Darling rivers. The main drivers behind basin closure are human activities aiming at augmenting, conserving, and reallocating the available water by investing in water infrastructure, such as reservoirs.

\section{Long-term dynamics}

While the negative impacts of reservoirs have been widely studied and are currently considered in water management and planning, we posit that there are long-term dynamics that should be considered when expanding reservoirs or designing water infrastructure: the supply-demand cycle ${ }^{33}$ and the reservoir effect. The supply-demand cycle describes instances where increasing water supply enables higher water demand, quickly offsetting the initial benefits of reservoirs. The reservoir effect refers to cases where over-reliance on water infrastructure increases vulnerability, and therefore increases the potential damage from water shortages.

We argue that we currently lack datasets and analytical tools to quantify these two phenomena. As the two long-term dynamics can occur within the planning horizon of reservoirs (20-30 years), these missing tools challenge the evaluation of strategies to reduce the negative impacts of drought and water shortage. In the next paragraphs, we describe these long-term dynamics based on our hypothesis depicted in Figure 2, and discuss various examples. We then propose a research call to unravel and quantify the feedback mechanisms between social, technical and hydrological processes, which can produce these two phenomena in different contexts. 


\section{Supply-demand cycles}

101 The supply-demand cycle refers to instances where increasing water supply enables agricultural, 102 industrial or urban expansion resulting in increasing competition for water resources ${ }^{33,34}$, thereby leading to a water demand higher than expected when considering socio-economic trends alone (Fig. 2, orange positive feedback loop). Consequently, the supply-demand cycle can quickly offset the initial benefits of reservoirs as an additional source of water supply.

The supply-demand cycle can be explained as a rebound effect, or Jevon's paradox ${ }^{35}$, which is wellknown in economics: as availability increases, consumption tends to increase. This rebound effect has been considered in water resources management and planning ${ }^{36,37}$, but mainly with reference to irrigation efficiency. The orange loop of Figure 2 shows that, in the context of reservoirs and water shortage, the rebound effect can potentially produce self-reinforcing (positive) feedbacks and lock-in conditions. The occurrence of a new water shortage may be addressed by further expansion of reservoir storage to, again, increase water supply ${ }^{29}$. Hence, the supply-demand cycle can trigger the unintended effect of an accelerating spiral towards unsustainable exploitation of water resources and environmental degradation.

We see the supply-demand cycle at the global scale when comparing annual water demand to storage capacity of large water supply reservoirs ${ }^{13}$. Figure 3 shows that water storage capacity has grown faster than water demand in the 1960 's (300\% vs. $15 \%$, respectively) and 1970's (130\% vs. $25 \%$ ). In more recent decades, however, demand has grown faster than storage capacity (e.g. $20 \%$ vs. $2 \%$, respectively, in the 1990's), thereby offsetting the initial benefits of many reservoirs. As a result, drought occurrences can trigger more severe water shortages or, if groundwater extraction is used to cope with drought, lead to significant aquifer depletion ${ }^{38,39}$.

The supply-demand cycle also exists at the local level. Here we show the water histories of three cities: Athens (Greece), Las Vegas (United States), and Melbourne (Australia). We focus on urban environments because the two long-term dynamics discussed here are more visible in cities. Furthermore, long time series of water demand are difficult to obtain for rural environments. Lastly, there is global concern about increasing urban water demand, which is expected to increase by $80 \%$ in $2050^{40}$.

The history of Athens has been intertwined with severe water shortages ${ }^{41}$. Over the past 150 years, the city has undergone a profound transformation: Kallis ${ }^{33}$ describes Athens in 1830, just after Greece's liberation, when thousands of Athenians returned home to find "nothing but piles of scattered ruins" and "people around water fountains waiting to fill their buckets, others pulling water from wells". The situation looks different in 2004: "four million people, no fountains or wells, but four large reservoirs and a complex system of canals supplying water to the city"33. The implementation of water infrastructure, from the Marathon dam to the Evinos dam (Fig. 4a), has continuously increased water supply. This process has not only met water needs, but has also enabled a growing population that, along with changing norms and habits ${ }^{33}$, has led to higher water demand and pressure on the available resources.

Lake Mead Reservoir was constructed in 1936 to provide water for California, Arizona and Nevada. At the time, Las Vegas had sufficient groundwater to meet demands. Later on, the Las Vegas Valley Water District built the Southern Nevada Water System to withdraw and distribute water from Lake Mead with the Colorado River pipeline and the In-take no. 1 (Fig. 4b). Following a logic similar to the one depicted in Figure 1, the original intention of this infrastructure was to cope with increasing demand in Las Vegas caused by socio-economic trends, i.e. a growing population that was projected to expand up to 400 thousand people by the end of the century ${ }^{44}$. However, Las Vegas' population grew much faster than expected and by the year 2000 was four times bigger ( 1.5 million). Our hypothesis (Fig. 2) is that this mismatch between projected and actual growth of water demand was partly related to the fact that increased water supply enabled urban growth, beyond growth expectations. This rapid growth continued into the early 2000's with Las Vegas being the fastest growing city in the US, in the fastest growing state since World War II ${ }^{45}$. In the 2000's, drought conditions threatened one of the in-take structures, which would have gone out of service if Lake Mead water levels had dropped further. As a result, in 2005 the Southern Nevada Water Authority board authorized the construction of a third and lower intake structure, which was completed in 2015 (In-take no. 3, Fig. 4b). 
Australia has experienced several droughts during the past 80 years, including three major events lasting more than five years ${ }^{46}$. In response to these multi-year droughts, Melbourne increased its storage capacity to prevent water shortages (Fig. 4c). The Thomson reservoir was added in 1984 with the intention to drought-proof Melbourne, increasing storage capacity by around $250 \%$. However, the additional storage led to more competition for water, as well as population and industrial growth, and subsequently significant increases in water demand were seen ${ }^{47}$. In 1984, the total water use was around three times higher than that in the 1940's (Fig. 4c). Accordingly, the supply-demand cycle in Melbourne is an illustrative example of how increased reservoir capacity can lead to increasing water consumption.

\section{Reservoir effects}

A second type of long-term dynamic associated with the expansion of water supply is termed here as the reservoir effect, following White's levee effect ${ }^{7,48}$. This phenomenon is related to instances when the construction of reservoirs reduces the incentive for adaptive actions on other levels (e.g. individuals, community), thus increasing the negative impacts of water shortages during severe droughts. In Figure 2 (red loop), we hypothesize that extended periods of abundant water supply, supported by reservoirs, generate an increasing dependence on water infrastructure, which in turn increases vulnerability and economic damage when water shortages eventually occur (Fig. 2, red loop).

In Melbourne, for example, the addition of reservoirs prevented water shortages only during minor drought conditions ${ }^{47}$. The anthropogenic increase in human water use in Melbourne not only doubled the severity of the Millennium Drought $(2001-2009)$ in terms of streamflows ${ }^{46}$, but also made the region more vulnerable to extreme and prolonged drought conditions because of increased reliance on reservoirs. The Millennium Drought demonstrated that, as a result of increased dependence on water resources, Melbourne's economy, agriculture and environment were severely affected ${ }^{47}$.

In Athens, the Mornos reservoir overflowed in 1985. This event created pride and political enthusiasm among the population, as Athens had -for the first time since becoming capital of the Greek state- more water available than needed ${ }^{40}$. As a result, in 1987, a new law declared water a "natural gift" and an "undeniable right" for every citizen ${ }^{40}$. The Mornos reservoir was considered sufficient for meeting water demands of areas not yet connected to the network. Two years later, however, when a severe drought occurred, the system was pushed to its operating limits and government responses were slow ${ }^{41}$. While inflows decreased in 1989 and 1990, withdrawals remained initially unchanged, and conservation measures were undertaken only when water availability became very critical ${ }^{41}$.

As for the introductory example of the Maya civilisation, additional storage of water initially brought many benefits and allowed agricultural growth under normal and minor drought conditions. Yet, the increased dependence on water resources made the population more vulnerable to extreme drought conditions, and plausibly contributed to the collapse of the Maya civilisation ${ }^{49}$.

The reservoir effect can also be explained as a safe development paradox ${ }^{50}$ : increased levels of safety can paradoxically lead to increasing damage. While this paradox has been widely documented in flood risk $^{7,48,51}$, it remains largely unexplored in regard to drought and water shortage. This is a major research gap because the safe development paradox is potentially more dangerous in the context of drought. More specifically, the increase of potential flood damage caused by higher reliance on levees ${ }^{7,48,51}$, or other structural protection measures, can be balanced by the corresponding reduction of the frequency of flooding ${ }^{51}$. Instead, the potential enhancement of drought damage due to increased reliance on reservoirs might not be counterweighed by a reduced frequency of shortages, if the supply-demand cycle quickly offsets the initial benefits of increased water supply.

\section{Interdisciplinary research call}

The two long-term dynamics described here, supply-demand cycle and reservoir effect, are caused by feedback mechanisms between human and natural systems, and by the interplay of technology and policy to manage hydrological variability. Although not explicitly put in these terms before, both phenomena have been discussed in different contexts ${ }^{33,49,52,53}$. Identifying the interactions between infrastructure and policy choices and emergent hydrological and social dynamics can inform more sustainable approaches. 
However, this is challenging as the feedback mechanisms generating these long-term dynamics remain poorly quantified. It is still unclear how relevant these phenomena are across different contexts, i.e. how diverse combinations of hydrological, technical, and social factors play a role in accelerating or mitigating the underlying feedback mechanisms. For instance, using the local examples above, research questions that we are still unable to address are: To what extent was the increasing demand in Athens after the construction of the Mornos Dam planned? To what extent has expanding water infrastructure in Las Vegas enabled its fast urban growth? What would have been the impact of the Millennium Drought on Melbourne had the Thompson Reservoir not been built?

This lack of knowledge prevents an explicit account of internal feedbacks and long-term dynamics in reservoir management and planning. As a result, policies and measures based on current methods might have unintended effects: the supply-demand cycle can produce an acceleration towards peak water limits ${ }^{54}$, while excessive reliance on water infrastructure (reservoir effect) can lead to damaging water shortages.

Thus, we call upon water managers, social scientists, policy makers, economists, ecologists and hydrologists to collaborate and develop datasets and analytical tools capturing the long-term dynamics produced by the interactions of physical, social and technical processes. To this end, we can draw upon new methods and concepts recently developed for the study of human-nature interactions in various interdisciplinary fields, e.g. social-ecological systems, sociohydrology and sustainability science ${ }^{55-60}$. More specifically, formulating and testing alternative hypotheses, such as the ones depicted in Figure 1 and 2, can guide the process of collecting useful data to explore the relative weight of internal and external factors in driving long-term dynamics. These hypotheses about feedback mechanisms and longterm dynamics can be used to build new models able to: i) quantify the way in which social, technical and hydrological factors interact and influence each other; and ii) capture the emergence of supplydemand cycles and reservoirs effects.

Locations that have faced consecutive water shortages and significant changes in water policies and infrastructure can be suitable study areas for exploring the causal mechanisms behind the supplydemand cycle and the reservoir effect. To unravel the chicken-and-egg dilemma about the causality of changes in water supply and demand, we also need to monitor behavioural changes during water shortages in both users (e.g. households, farmers) and decision makers (e.g. water authorities), and how such responses are in turn influenced by the reliance on water infrastructure. This requires a more systematic monitoring of vulnerability changes across decades, such as longitudinal studies, and motivates new data collections and aggregation efforts.

The hypothesis-driven research proposed here can help reveal what can, or cannot, be generalized, and develop new tools to project the long-term effects of reservoirs, and other types of water infrastructure, on the spatiotemporal (re)distribution of both water supply and demand.

\section{References}

1. Dunning, N. P., Beach, T. P., \& Luzzadder-Beach, S. Collapse and resilience in lowland Maya civilization. Proc. Natl. Acad. Sci. 109, 3652-3657 (2012).

2. Jaramillo, F. \& Destouni, G. Local flow regulation and irrigation raise global human water consumption and footprint. Science 350, 1248-1251 (2015).

3. Vörösmarty, C.J. Pahl-Wostl, C., Bunn, S., \& Lawford, R. Global water, the Anthropocene and the transformation of science. Current Opinion in Environmental Sustainability 5, 539550 (2013).

4. AghaKouchak, A., Feldman, D., Hoerling, M., Huxman, T. \& Lund, J. Water and climate: Recognize anthropogenic drought. Nature 524, 409-4011 (2015).

5. Van Loon, A.F., Gleeson, T., Clark, J., Van Dijk, A.I.J.M., Stahl, K., Hannaford, J., Di Baldassarre, G., Teuling, A.J., Tallaksen, L.M., Uijlenhoet, R., Hannah, D.M., Sheffield, J., Svoboda, M., Verbeiren, B., Wagener, T., Rangecroft, S., Wanders, N. \& Van Lanen, H.A.J. Drought in the Anthropocene. Nature Geoscience 9, 89-9 (2016).

6. Wanders, N., Wada, Y. \& Van Lanen, H.A.J. Global hydrological droughts in the 21st century under a changing hydrological regime. Earth Syst. Dynam. 6, 1-15 (2015). 
7. Di Baldassarre, G. Martinez, F., Kalantari, Z. \& Viglione, A. Drought and flood in the Anthropocene: feedback mechanisms in reservoir operation, Earth Syst. Dynam. 8, 225-233 (2017).

8. Veldkamp, T.I.E., Wada, Y. Aerts, J.C.J.H., Döll, P., Gosling, S.N., Liu, J., Masaki, Y., Oki, T., Ostberg, S., Pokhrel, Y., Satoh, Y., Kim, H. \& Ward P.J. Water scarcity hotspots travel downstream due to human interventions in the 20th and 21st century, Nature Communications 8, 15697 (2017).

9. Gaupp, F., Hall, J. \& Dadson, S. The role of storage capacity in coping with intra- and interannual water variability in large river basins. Environ. Res. Lett. 10, 125001 (2015).

10. Ehsani, N., Vörösmarty, C.J., Fekete, B.M. \& Stakhiv, E.Z. Reservoirs operations under climate change: storage capacity options to mitigate risk. Journal of Hydrology 555, 435-446 (2017).

11. Pokhrel, Y. N., Hanasaki, N., Wada, Y. \& Kim, H. Recent progresses in incorporating human land - water management into global land surface models toward their integration into Earth system models. WIREs Water, 3, 548-574 (2016).

12. Lehner, B., Liermann, C.R., Revenga, C., Vörösmarty, C., Fekete, B., Crouzet, P., Döll, P., Endejan, M., Frenken, K., Magome, J., Nilsson, C., Robertson, J. C., Rödel, R., Sindorf, N. \& Wisser, D. High-resolution mapping of the world's reservoirs and dams for sustainable riverflow management. Frontiers in Ecology and the Environment 9, 494-502 (2011).

13. Chao, B.F., Wu, Y.H. \& Li, Y.S. Impact of artificial reservoir water impoundment on global sea level. Science 320, 212-214 (2008).

14. Vörösmarty, C.J., Meybeck, M., Fekete, B., Sharma, K., Green, P., \& Syvitski, J.P.M. Anthropogenic sediment retention: Major global impact from registered river impoundments. Global and Planetary Change 39, 169-190 (2003).

15. Wada, Y., Gleeson, T. \& Esnault, L. Wedge approach to water stress. Nature Geoscience 7, 615-617 (2014).

16. Vörösmarty, C. J., Green, P., Salisbury, J., \& Lammers, R.B. Global water resources: vulnerability from climate change and population growth. Science, 289, 284-288 (2000).

17. Brown, C. \& Lall, U. Water and economic development: The role of variability and a framework for resilience. Natural Resources Forum 30, 306-317 (2006).

18. Briscoe, J. Water Security: Why It Matters and What to Do about It. Innovations: Technology, Governance, and Globalization 4, 3-28 (2009).

19. Gray, D. \& Sadoff, C.W. Water for Growth and Development (2006).

20. Briscoe, J. Practice and Teaching of American Water Management in a Changing World. Journal of Water Resources Planning and Management 136, 409-411 (2010).

21. Gleick, P. H. Global freshwater resources: soft-path solutions for the 21st century. Science, 302, 1524-1528 (2003).

22. Ahlers, R., Brandimarte, L., Kleemans, I. \& Hashmat Sadat S. Ambitious development on fragile foundations: Criticalities of current large dam construction in Afghanistan, Geoforum 54, 49-58 (2014).

23. Gernaat, D.E.H.J., Bogaart, P.W., van Vuuren, D.P., Biemans H. \& Niessink R. HighResolution Assessment of Global Technical and Economic Hydropower Potential, Nature Energy 2, 821-828 (2017).

24. Ansar, A., Flyvbjerg, B., Budzier, A. \& Lunn, D. Should we build more large dams? The actual costs of hydropower megaproject development. Energy Policy 69, 43-56 (2014).

25. Latrubesse, E. M., Arima, E. Y., Dunne, T., Park. E., Baker, V. R., d’Horta, F. M., Wight, C., Wittmann, F., Zuanon, J., Baker, P. A., Ribas, C. C., Norgaard, R. B., Filizola, N., Ansar, A., Flyvbjerg, B. \& Stevaux, J. C. Damming the rivers of the Amazon basin. Nature 546, 363-369 (2017).

26. Wanders, N. \& Y. Wada Y. Human and climate impacts on the 21st century hydrological drought. Journal of Hydrology 526, 208-220 (2015).

27. He, X., Wada, Y., Wanders, N. \& Sheffield J. Intensification of hydrological drought in California by human water management. Geophysical Research Letters, in press (2017). 
28. AghaKouchak A., Norouzi H., Madani K., Mirchi A., Azarderakhsh M., Nazemi N., Nasrollahi N., Mehran M., Farahmand A. \& Hasanzadeh E. Aral Sea Syndrome Desiccates Lake Urmia: Call for Action, Journal of Great Lakes Research, 41, 307-311 (2015).

29. Alborzi A., et al., Climate-Informed Environmental Inflows to Revive a Drying Lake Facing Meteorological and Anthropogenic Droughts, Environmental Research Letters, 13, 084010 (2018).

30. Ashraf, B., et al. Quantifying Anthropogenic Stress on Groundwater Resources, Scientific Reports 7, 12910, doi: 10.1038/s41598-017-12877-4 (2017).

31. Molle, F., Wester, P. \& Hirsch P. River basin closure: Processes, implications and responses. Agricultural Water Management, 97, 569-577 (2010).

32. Van Oel, P.R., Krol, M.S. \& Hoekstra, A.Y. Downstreamness: A Concept to Analyze Basin Closure. Journal of Water Resources Planning and Management, 137, 404-411 (2011).

33. Kallis, G. Coevolution in water resource development: The vicious cycle of water supply and demand in Athens, Greece. Ecol. Econ. 69, 796-809 (2010).

34. Scarrow, R.M. Sustainable Migration to the Urban West. International Journal of Sociology 44, 34-53 (2014).

35. Alcott, B. "Jevons' paradox". Ecological Economics. 54, 9-21 (2005).

36. Berbel, J., C. Gutiérrez-Martín, J.A. Rodríguez-Díaz, E. Camacho, \& Montesinos, P. Literature Review on Rebound Effect of Water Saving Measures and Analysis of a Spanish Case Study. Water Resources Management, 29, 663-678 (2014).

37. Dumont, A., Mayor, B., \& López-Gunn, E. Is the rebound effect or Jevons paradox a useful concept for better management of water resources? Insights from the Irrigation Modernisation Process in Spain. Aquatic Procedia, 1, 64-76 (2013).

38. Taylor, R. Ground water and climate change. Nature Climate Change 3, 322-329 (2013)

39. Gleeson, T., Wada, Y., Bierkens, M. F., \& van Beek, L.P. Water balance of global aquifers revealed by groundwater footprint. Nature 488, 197-200 (2012).

40. Flörke, M. Schneider C., \& McDonald R.I. Water competition between cities and agriculture driven by climate change and urban growth, Nature Sustainability, 1, 51-58 (2018).

41. Karavitis, C.A. Drought and urban water supplies: the case of metropolitan Athens. Water Policy 1, 505-524 (1998).

42. Harrison, C. Water use and natural limits in the Las Vegas Valley: A history of the Southern Nevada Water Authority (University of Nevada, 2009).

43. Morris, R., Devitt, D. A., Crites, Z. A. M., Borden, G., \& Allen, L.N. Urbanization and Water Conservation in Las Vegas Valley, Nevada. J. Water Resources Planning \& Management 123, 189-195 (1997).

44. SNWA. Water Resources Management Plan (Las Vegas, 2009).

45. Douglass, W. \& Raento, P. The Tradition of Invention: Conceiving Las Vegas. Annals of Tourism Research 31, 7-23 (2004).

46. van Dijk, A.I.J.M., Beck, H.E., Crosbie, R.S., de Jeu, R.A.M., Liu, Y.Y., Podger, G.M., Timbal, B. \& Viney N.R. The Millennium Drought in southeast Australia (2001-2009): Natural and human causes and implications for water resources, ecosystems, economy, and society, Water Resour. Res. 49, 1040-1057 (2013).

47. Hemati, A. et al. Deconstructing Demand: The Anthropogenic and Climatic Drivers of Urban Water Consumption. Environ. Sci. Technol. 50 12557-12566 (2016).

48. Kates, R. W., Colten, C.E., Laska, S. \& Leatherman S.P. Reconstruction of New Orleans after Hurricane Katrina: A research perspective. Proc. Natl. Acad. Sci. 103, 14653-14660 (2006).

49. Kuil, L., Carr, G., Viglione, A., Prskawetz, A. \& Blöschl, G. Conceptualizing sociohydrological drought processes: The case of the Maya collapse. Water Resourc. Res. 52, 62226242 (2016).

50. Burby, R.J. Hurricane Katrina and the paradoxes of government disaster policy: Bringing about wise governmental decisions for hazardous areas. Ann. Am. Acad. Political Social. Sci. 604, 171-191 (2006).

51. Di Baldassarre, G., Viglione, A., Carr, G., Kuil, L., Yan, K., Brandimarte, L. \& Blöschl, G. Perspectives on socio-hydrology: Capturing feedbacks between physical and social processes, Water Resour. Res., 51, 4770-4781 (2015). 
52. Ashton, P. J., Hardwick, D., \& Breen, C. M. Changes in water availability and demand within South Africa's shared river basins as determinants of regional social-ecological resilience. Exploring Sustainability Science: A Southern African Perspective. 279-310 (2008).

53. Anderies, J. M. Managing variance: Key policy challenges for the Anthropocene. Proc. Natl. Acad. Sci. 112, 14402-14403 (2015).

54. Gleick, P. H., \& Palaniappan, M. Peak water limits to freshwater withdrawal and use. Proceedings of the National Academy of Sciences, 107, 11155-11162 (2010).

55. Burton, I., Kates, R.W. \& White, G.F. The human ecology of extreme geophysical events, Natural Hazard Research (University of Toronto, 1968).

56. Ostrom, E., A General Framework for Analyzing Sustainability of Social-Ecological Systems. Science 325, 419-422 (2009).

57. Sivapalan, M., Savenije, H. H., \& Blöschl, G. Socio-hydrology: A new science of people and water. Hydrol. Process. 26, 1270-1276 (2012).

58. Birkmann, J., von Teichman, K., Integrating disaster risk reduction and climate change adaptation: key challenges—scales, knowledge, and norms, Sustain. Sci., 5 171-184 (2010).

59. Srinivasan, V., Lambin, E.F., Gorelick, S. M., Thompson, B. H. \& Rozelle, S. The nature and causes of the global water crisis: Syndromes from a meta-analysis of coupled human-water studies, Water Resour. Res. 48, W10516 (2012).

60. Adger, N., Quinn, T., Lorenzoni, I., Murphy, C. \& Sweeney, J. Changing social contracts in climate-change adaptation, Nature Climate Change 3, 112-117 (2013).

61. Wada, Y., van Beek, L.P.H., Wanders, N. \& Bierkens, M.F.P. Human water consumption intensifies hydrological drought worldwide. Environ. Res. Lett. 8, 034036 (2013).

62. Lehner, B., Verdin, K. \& Jarvis, A. New global hydrography derived from spaceborne elevation data, Eos 89, 93-94 (2008).

63. Verdon-Kidd, D.C. \& Kiem, A.S. Nature and causes of protracted droughts in southeast Australia: Comparison between the Federation, WWII, and Big Dry droughts, Geophys. Res. Lett. 36, L22707 (2009).

\section{Acknowledgements}

Correspondence and requests for materials should be addressed to Giuliano Di Baldassarre (giuliano.dibaldassarre@geo.uu.se). G.D.B. was supported by the European Research Council (ERC) within the project "HydroSocialExtremes: Uncovering the Mutual Shaping of Hydrological Extremes and Society”, ERC Consolidator Grant No. 771678. N.W. acknowledges the funding from NWO 016.Veni.181.049. S.R. and A.F.V.L. were supported by the NWO project "Adding the human dimension to drought" (2004/08338/ALW). This work was developed within the activities of the working group on Drought in the Anthropocene of the Panta Rhei research initiative of the International Association of Hydrological Sciences (IAHS).

\section{Author contributions}

G.D.B. conceived the study and wrote the manuscript. N.W. developed the global analysis of reservoir storage analysis and water demand. A.A., L.K., S.R., T.I.E.V., M.G., P.R.v.O., K.B. and A.F.V.L. contributed data or insights, discussed the argument, and edited the manuscript.

\section{Competing interests}

The authors declare no competing financial interests. 


\section{$411 \quad$ Figures}

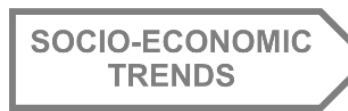

Water

Demand

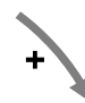

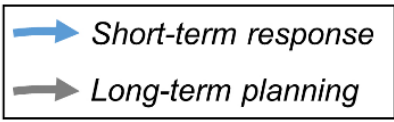

Water Shortage<smiles>C1CCCCC1</smiles>
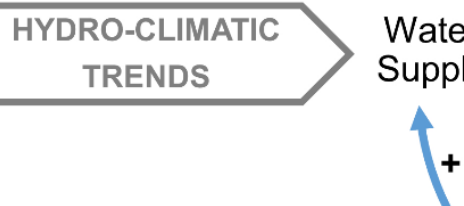

414
Figure 1 | Water supply to cope with water shortage. The causal loop diagram shows the positive $(+)$ and negative (-) feedbacks between physical, technical and social processes. This diagram is based on traditional approaches in water management and long-term planning that emphasise the role of external drivers of change (big grey arrows): socio-economic trends influencing water demand, and hydro-climatic trends influencing water supply. 


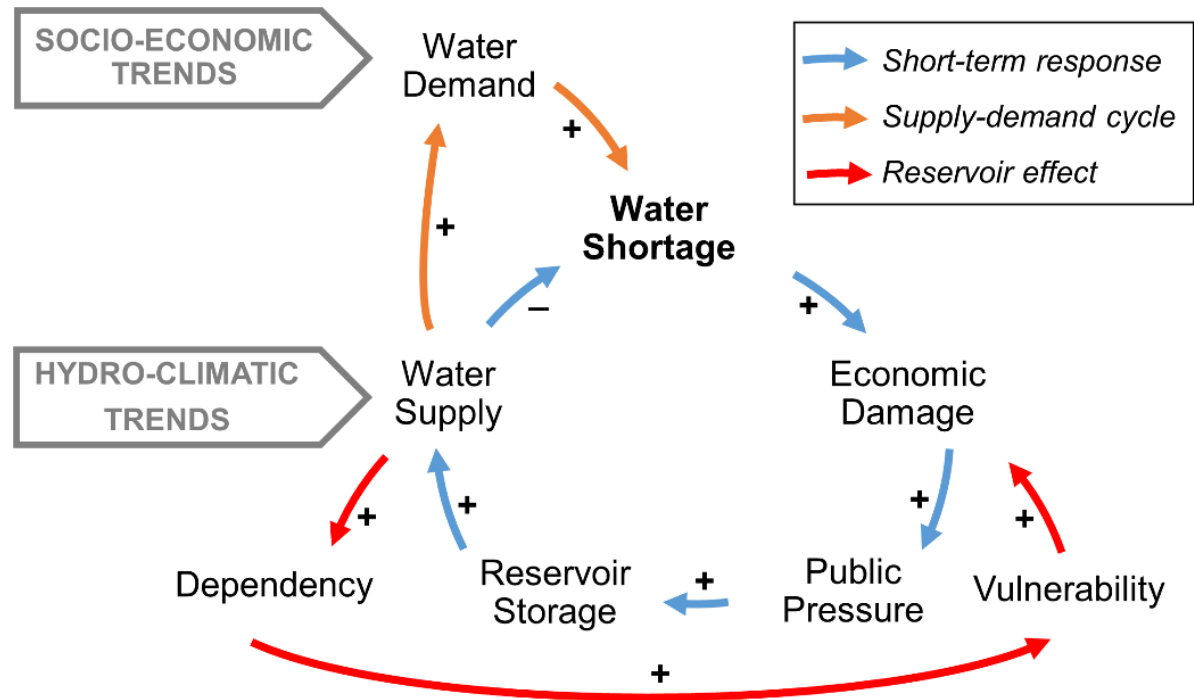

423 Figure 2 | Water supply can worsen water shortage. The causal loop diagram shows the positive $424(+)$ and negative (-) feedbacks between physical, technical and social processes. Our hypothesis 425 emphasises the role of internal feedback mechanisms, and the potential emergence of long-term dynamics: supply-demand cycle (orange loop) and reservoirs effect (red loop). 


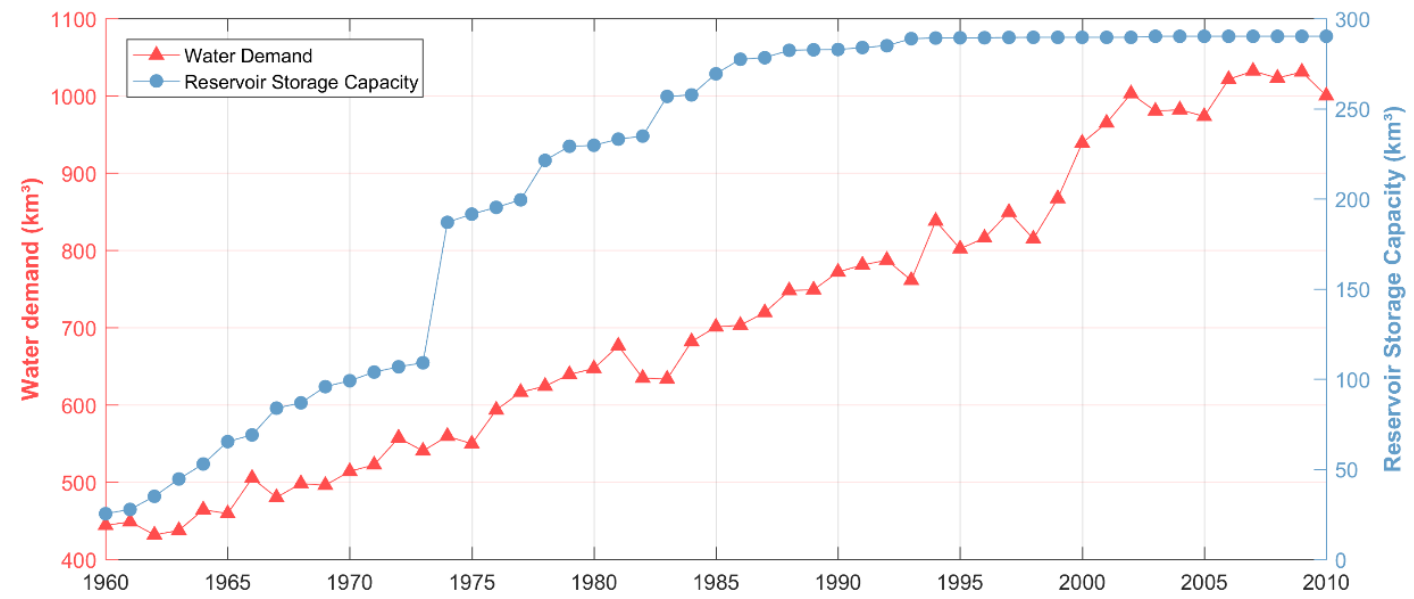

430 Figure 3 | Global reservoir storage capacity versus water demand. Data over the past five decades from World Bank statistics and GRanD database ${ }^{12}$. Storage capacity refers only to reservoirs that have water supply or irrigation as one of their main purposes in the GRanD database. Annual water demand ${ }^{61}$ refers to areas downstream of these reservoirs as derived from the HydroSHEDS ${ }^{62}$ draining network. We assume that the reservoir dependency is limited to $200 \mathrm{~km}$ downstream of reservoirs. 

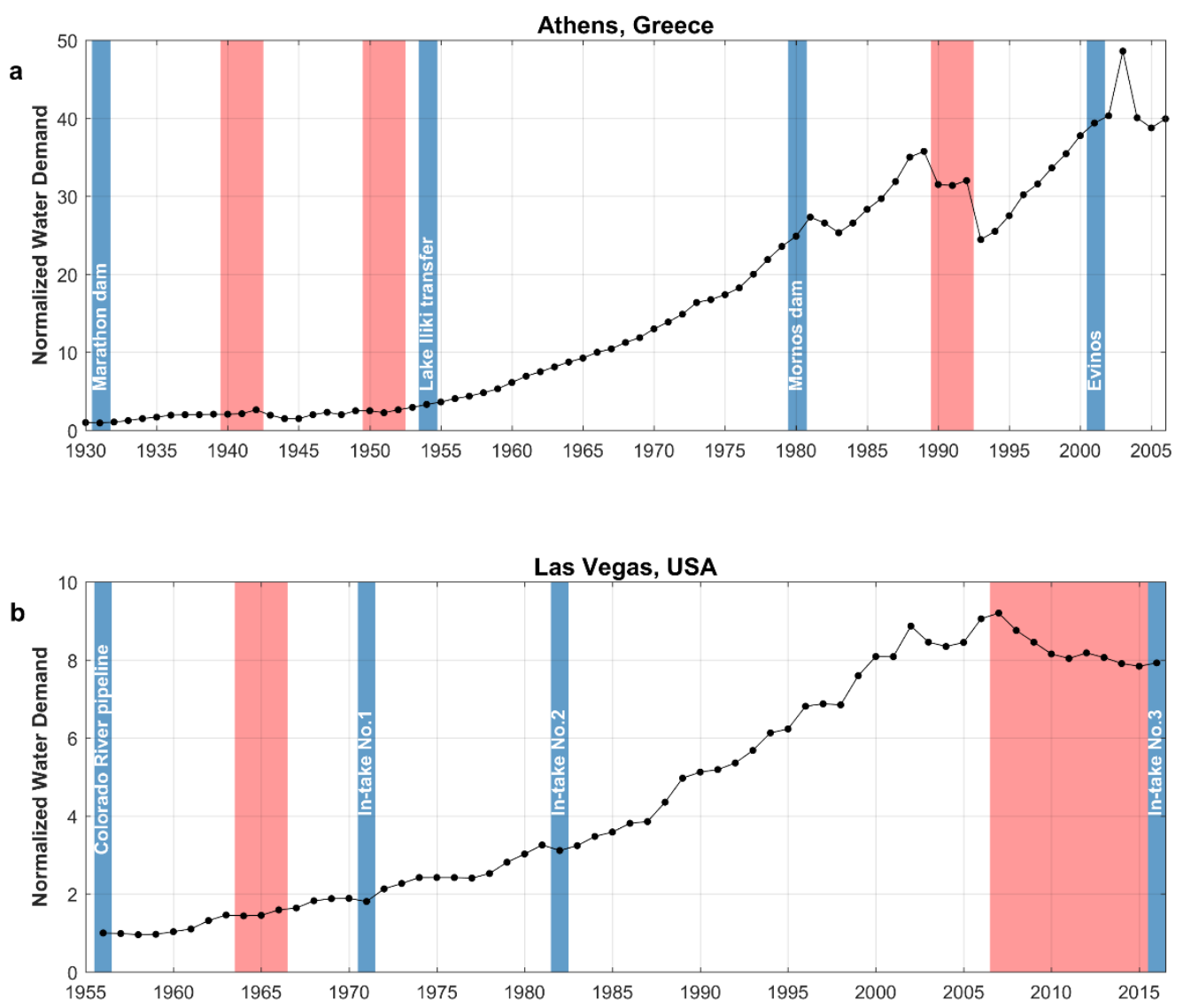

Figure 4 | Local examples of the supply-demand cycles over multiple decades: (a) Athens, (b) Las Vegas and (c) Melbourne. Time series of annual water demand normalized by its initial value (black line) and timing of the main measures that significantly increased water supply (blue). Drought periods (red) were derived from literature for Athens ${ }^{33}$ and Melbourne ${ }^{63}$, and from the periods in which the annual water levels in the Lake Mead were lower than 1100 feet and potentially affecting water supply to Las Vegas. Data sources: EYDAP, South Nevada Water Authority (SNWA), US

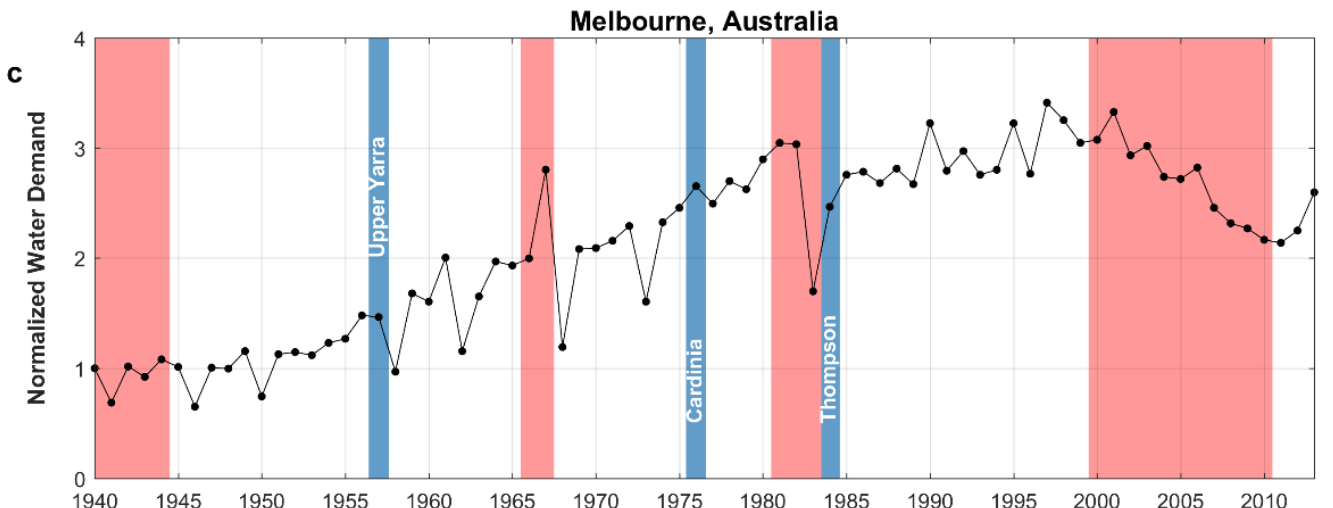

